\title{
Det åbne vejledningsrum
}

Rie Troelsen ${ }^{1}$, Leder af SDU-Universitetspædagogik, Syddansk Universitet

Jeg har i mange år afholdt korte endagskurser for vejledere om roller og relationer i vejledningssituationen. Deltagere i disse kurser er enten i gang med deres Universitetspædagogikum og/eller ansat på et institut, hvor initiativrige institutledere, studieledere eller kolleger har inviteret mig til at sætte fokus på vejledning hos dem. Vi taler så om forventningsafklaring, vejledningsstrategier og spørgsmålstyper, og om hvordan dilemmafyldte vejledningssituationer kan forstås, forklares og måske forløses ved at overveje de tre emner.

For langt de fleste kursusdeltagere er det første gang de har lejlighed til at reflektere over deres vejledningspraksis og dele deres erfaringer med andre. Hvor vi i de seneste 10-20 år er blevet bedre og bedre til at afprivatisere undervisningsrummet ved at udveksle ideer til undervisningsmetoder, invitere kolleger ind for at observere og efterfølgende diskutere vores undervisning, og italesætte og anerkende gode undervisere igennem lokale og nationale undervisningspriser, så er vejledningsrummet stadig en lidt mere privat sag. Det er ikke så almindeligt, at man taler med sine kolleger over frokostbordet om hvilke vejledningsmetoder, der er virksomme til særlige vejledningsemner, ligesom det hører til sjældenhederne, at kolleger sidder med hos hinanden i vejledningssituationer for at blive inspireret til egen vejledningspraksis. Vejledning er i udpræget grad en sag mellem vejlederen og de( $n$ ) vejledte.

Men skal vi udvikle vejledningen (og vejlederne) er det vigtigt, at vi også åbner for vejledningsrummet og synliggør for os selv, hinanden og de studerende, hvad der er på færde i vejledningssituationen. Og for at nå så langt, er det selvfølgelig vigtigt at betragte vejledningen som enhver anden undervisningssituation med en didaktik, som kan diskuteres og deles og reflekteres over: Hvad er formålet med vejledningen, hvilke forudsætninger har den vejledte, hvilke forudsætninger har du som vejleder, hvilke vejledningsaktiviteter/metoder kan tages i brug, hvilke rammer foregår vejledningen i, osv.

Og her kommer DUT ind i billedet! En måde at få startet diskussioner og erfaringsudvekslinger - blandt kolleger over frokostbordet såvel som på korte endagskurser - om hvad der er på færde i vejledningssituationen, er at læse om det i DUT. I dette nummer af DUT kan du fx læse om hvilke vejledningserfaringer, de nye studerende bringer med sig ind på universitetet, hvordan faglig vejledning ikke kun kan forstås som en primært ansigt-tilansigt pædagogik, men også en stemme-til-stemme pædagogik, og hvordan en student-as-partners proces kan fungere i en specialevejledningssituation. Samtidig får du også en DUT guide med gode råd og handleanvisninger til vejlederen. Naturligvis sammen med flere artikler om universitetspædagogiske emner uden for vejledningsrummet.

Pointen er, at udvikling kræver refleksion og dokumentation for at synliggøre for os selv og andre, hvor vi står nu, og hvad vi kan gøre anderledes fremover. Derfor er det faktisk ikke nok, at du nu går i gang med at læse dig igennem og blive inspireret af dette DUT-nummers artikler - du skal også i gang med at afprøve, reflektere,

\footnotetext{
${ }^{1}$ Kontakt: riet@sdu.dk
} 
diskutere og evt. skrive om det selv. Åbn dit vejledningsrum for dig selv og andre og lad os sammen udvikle vejledningspraksis!

\section{Betingelser for brug af denne artikel}

Denne artikel er omfattet af ophavsretsloven, og der må citeres fra den.

Følgende betingelser skal dog være opfyldt:

- Citatet skal være i overensstemmelse med "god skik"

- Der må kun citeres „i det omfang, som betinges af formålet"

- Ophavsmanden til teksten skal krediteres, og kilden skal angives ift. ovenstående bibliografiske oplysninger

(C) Copyright

DUT og artiklens forfatter
Udgivet af

Dansk Universitetspædagogisk Netværk 